\title{
Antibacterial Effect and Deodorization Effect of Extracts from Different Parts of Zingiber officinale
}

\author{
Young Suk Lee ${ }^{1}$, Young Ju Kang ${ }^{2}$, Min Jeong Ryu ${ }^{3 *}$ \\ ${ }^{1}$ Su Mi Beauty Salon, Daegu, Korea \\ ${ }^{2} J$ usighoesa Gat-eunsaeng-gag, Daegu, Korea \\ ${ }^{3}$ Department of Cosmetology Science, Nambu University, Gwangju, Korea
}

\author{
*Corresponding author: Min Jeong Ryu, \\ Department of Cosmetology Science, \\ Nambu University, 23 advanced Jungang- \\ ro, Gwangsan-gu, Gwangju 62271, Korea \\ Tel.: +82629700137 \\ Fax: +82629726200 \\ Email: jemine0806@hanmail.net
}

Received August 06, 2020

Revised November 02, 2020

Accepted November 24, 2020

Published December 30, 2020

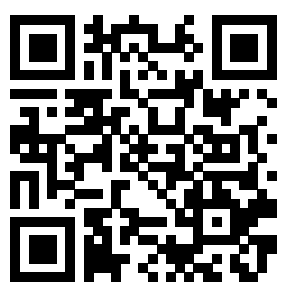

\begin{abstract}
Purpose: Using extracts from different parts of Zingiber officinale, we aimed to evaluate its antibacterial effect on skin flora and its deodorization effect on ammonia to determine its potential as an antimicrobial ingredient and functional herbal cosmetic ingredient. Methods: The antibacterial effect on skin flora was examined using the paper disc method and the deodorization effect on ammonia was examined by the gas detection method. Results: After evaluating the antibacterial effects of extracts from different parts (leaves, stems, and roots) of Zingiber officinale, antibacterial activity was observed against Staphylococcus aureus ( $S$. aureus) at a concentration of $5 \mathrm{mg} / \mathrm{mL}$. The leaf, stem, and root extracts had 3 $\mathrm{mm}, 3 \mathrm{~mm}$, and $2 \mathrm{~mm}$ clear zones, respectively. For the antibacterial effect against Staphylococcus epidermidis (S. epidermidis), there were $8 \mathrm{~mm}, 5 \mathrm{~mm}$, and $4 \mathrm{~mm}$ clear zones for the leaf, stem, and root extracts, respectively. For Propionibacterium acnes ( $P$. acnes), a bacterium that causes acne, there were $4 \mathrm{~mm}, 3 \mathrm{~mm}$, and $1 \mathrm{~mm}$ clear zones for the leaf, stem, and root extracts, respectively. The results for Pityrosporum ovale ( $P$. ovale) showed $6 \mathrm{~mm}, 5 \mathrm{~mm}$, and $4 \mathrm{~mm}$ clear zones for the leaf, stem, and root extracts, respectively. For Malassezia furfur ( $M$. furfu), there were $4 \mathrm{~mm}, 3 \mathrm{~mm}$, and $2 \mathrm{~mm}$ clear zones for the leaf, stem, and root extract, respectively. For Candida albicans (C. albicans), there were $4 \mathrm{~mm}, 3 \mathrm{~mm}$, and $2 \mathrm{~mm}$ clear zones for the leaf, stem, and root extracts, respectively. Finally, after evaluating the antibacterial effect against Trichophyton mentagrophytes (T. mentagrophytes) at a concentration of 5 $\mathrm{mg} / \mathrm{mL}$, we found $6 \mathrm{~mm}, 4 \mathrm{~mm}$, and $3 \mathrm{~mm}$ clear zones for the leaf, stem, and root extracts, respectively. After evaluating the deodorization effects of Zingiber officinale extracts on ammonia, at $120 \mathrm{~min}$, the deodorization effect was $98 \%$, 95\%, and 91\% for the leaf, stem, and root extracts, respectively. Conclusion: Among the three extracts of Zingiber officinale, the leaf extract had the highest antibacterial effect against the seven types of skin flora as well as the highest deodorization effect, thus confirming its potential as an antibacterial ingredient and functional herbal cosmetic ingredient.
\end{abstract}

Keywords: Zingiber officinale, Antibacterialt, Deodorization, Ammonia, Cosmetic

\section{Introduction}

사람의 몸에서 땀, 피지가 많이 발생하는 두피, 겨드랑이, 손발바 닥, 생식기 등에서 체취가 발생하고 있으며, 땀이 지나치게 배출되 면 각질층에 살고 있는 피부상재균들이 각질을 분해하면서 이상 과 증식을 하고 발 냄새와 같은 악취의 원인이 된다(Ahn et al., 2012).
생활속에서 발생되는 대표적인 악취물질로는 ammonia, hydrogen sulfide, trimethylamine, methylmercapta등의 화합물이 있으며 이 는 전체 악취물질 중 $80 \%$ 이상을 차지하고 있다. 특히 이러한 화합물 들은 유기물이 부패할 때 발생되므로 항균 작용을 통해 부패를 방지 함으로써 악취의 원인을 제거 할 수 있다(Hwang et al., 2014). 인간의 피부에는 피부상재균인 미생물이 생식하고 있으며 이들 피 
부상재균은 피지막의 일부를 구성하고 피부를 약산성으로 유지하며, 건조, 자외선으로부터 피부를 지키고 병원균의 침입을 막는 등 피부 의 건강에 있어 유익한 역할을 하고 있다(Kim \& So, 2016). 일반적 으로 건강한 피부의 경우 유익균과 유해균이 8:2의 비율로 유지하며 약산성을 이루어 균형을 유지하며 땀으로 분비되는 면역 항체와 결 합하여 피부의 면역력을 높여주지만, 잘못된 생활습관, 신체 리듬의 불균형, 과도한 유지 공급, 불안정한 호르몬 생성을 통한 과도한 피 지 분비 유도에 의하여 항상성이 파괴된다(Ko et al., 2018; Lee \& Ryu, 2019). 피지가 모공 밖으로 배출되지 못하면 모공 내로 역류되 거나 모공을 막아 염증을 유발하거나 피부를 과각질화시켜 피부 질환 을 유발하는 세균의 번식을 초래한다(Kim et al., 2017). 많은 피부질 환이 피부상재균에 의해 발생되며 이 중 S. epidermidis, $S$. aureus, P. acnes, P. ovale, M. furfu, C. albicans, T. mentagrophytes는 여드름 및 아토피 등 대표적인 피부질환과 관련된 균주이다(Lee et al., 2018). 피부상재균 이외에도 화장품을 변질시키는 세균도 피부 에 악영향을 주고 있으며, 주거공간 내의 곰팡이 발생은 질병을 유발 한다. 이를 사멸하기 위해 다양한 종류의 항균제나 방부제를 필수적 으로 사용하고 있는데 기존에 사용되고 있는 합성물질들은 인체에 알 레르기를 유발하기도 한다. 따라서 인체에 안전하면서도 항균성, 방 부력을 가진 천연소재에 관한 연구가 필요한 시점이다(Lim \& Hong, 2016; Kim et al., 2018). 생강(Zingiber offcinale Roscoe)은 열대 아시아가 원산지인 생강과에 속하는 다년생 초본 식물의 하나로써, 그의 근경을 칭하기도 한다. 생강은 특유의 맛과 향기를 지니고 있어 기호성이 좋은 향신료의 하나로써 날 생강, 건 생강, 정유(absolute, oleoresin) 등이 생강 제품을 위한 소재로 유통되고 있다(Lee et al., 2011). 생강에 대한 국내 연구는 마우스의 대장염 억제 효과(Kim et al., 2014), 항산화 효과(Guon \& Chung, 2016; Jung \& Park, 2013; Lee et al., 2020), 전립선비대 억제효과( Kim et al., 2020), 식품 첨가 관련 연구(Hwang et al., 2015; Han \& Kim, 2011; Kim $\&$ Lee, 2019; Lee, 2014)등이 보고되었다.

따라서 본 연구에서는 생강 잎, 줄기, 뿌리 추출물의 피부상재균에 대한 항균효과 및 암모니아에 대하 소취능을 평가하여 항균소재 및 기능성 향장품소재로서의 가능성을 예측하고자 한다.

\section{Methods}

\section{1. 시료 추출}

시료 추출은 생강 전체를 잎, 줄기, 뿌리로 분리하여 각각 $100 \mathrm{~g}$ 에 $70 \%$ 주정 에탄올 $1 \mathrm{~L}$ 를 가하여 $60^{\circ} \mathrm{C}$ 에서 $24 \mathrm{~h}$ 추출하고, 추출액 을 여과(Whatman filter paper No.1; Whatman, UK)한 후에 회 전식 감압농축기(EYELA N-1000; Tokyo Rikakikai Co, Japan)로 농축한 후, 동결건조기 (PVTFA 10AT; ILSIN, Korea)에 $72 \mathrm{~h}$ 동안 동결 건조하여 분말로 만들어 실험을 진행하였다.

\section{2. 항균활성에 사용된 균주 및 배양}

항균활성에 사용된 미생물 균주는 한국생명공학연구원 생물자원 센터(KCTC/BRC, Korea), 한국미생물 보존센터(KCCM, Korea)에 서 분양 받았다, 실험에 사용한 각 미생물 균주, 배지 및 배양조건은 Table 1에 정리하였다.

\section{Paper disc에 의한 생강 부위별 추출물의 항균활성 측정}

생강 부위별 추출물의 항균활성을 dise diffusion assay로 측정 하였다 (Davidson \& Parish, 1989). 순수 분리된 각 균을 취해 10 $\mathrm{mL}$ 의 액체배지에 접종하여 각각 균의 생육적온에서 24 시간씩 3 회 배양 후 항균활성 시험 균으로 사용하였다. 각각의 시험 균 농도 를 $650 \mathrm{~nm}$ 에서 optical density (O.D)값이 $0.4\left(10^{6} \mathrm{CFU} / \mathrm{mL}\right)$ 가 되 게 한 후 $0.7 \%$ 한천이 첨가된 배지에 잘 혼합한 다음 평판배지 위 에 분주하여 균 접종 배지를 만들었다. 멸균된 paper disc $(8 \mathrm{~mm}$; Advantec, Japan)를 균 접종 배지 표면에 올려놓은 후 $0.25-5 \mathrm{mg} /$ $\mathrm{mL}$ 가 되도록 생강 잎, 줄기, 뿌리 추출물을 흡수시킨 다음 $26-$ $37^{\circ} \mathrm{C}$ 에서 $24 \mathrm{~h}$ 동안 배양 후 disc 주위의 clear zone을 측정하였다. Clear zone은 paper disc의 직경을 포함하지 않았다. 음성 대조구로 는 $25 \%$ ethanol 을 사용하였다.

\section{4. 생강 부위별 추출물의 소취효과 측정}

생강 부위별 추출물의 소취효과는 유기오염 물질인 암모니아 가 스 제거 실험을 하였다. 암모니아의 소취율은 가스검지관법(KFIA-

Table 1. List of microorganism used for antimicrobial experiment

\begin{tabular}{lccc}
\hline Strains & Gram Strain & Media & Temp \\
Staphylococcus epidermidis & Gram (+) & TSB & $37{ }^{\circ} \mathrm{C}$ \\
Staphylococcus aureus & Gram (+) & TSB & $37{ }^{\circ} \mathrm{C}$ \\
Propionibacterium acnes & Gram (+) & RCM & $37{ }^{\circ} \mathrm{C}$ \\
Pityrosporum ovale & Yeast & YMB & $37{ }^{\circ} \mathrm{C}$ \\
Malassezia furfur & Yeast & YMB & $30{ }^{\circ} \mathrm{C}$ \\
Candida albicans & Yeast & LB & $37{ }^{\circ} \mathrm{C}$ \\
Trichophyton mentagrophytes & Fungal & SDB & $26{ }^{\circ} \mathrm{C}$ \\
\hline
\end{tabular}

TSB, trypticase soy broth; RCM, reinforced clostridial medium; YMB, yeast medium broth; LB, lactose broth; SDB, sabouraud dextrose broth. 

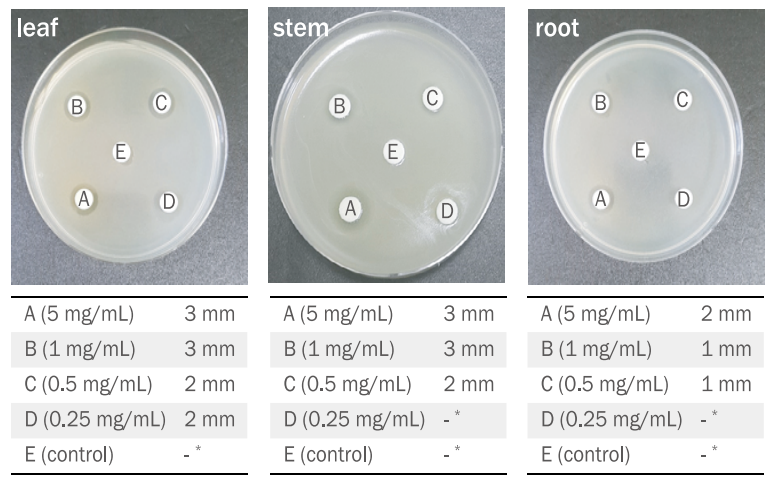

Figure 1. Clear zone diameters of leaf, stem, and root extracts of Zingiber officinal on the growth of Staphylococcus aureus.

A, $5 \mathrm{mg} / \mathrm{mL}$; B, $1 \mathrm{mg} / \mathrm{mL}$; C, $0.5 \mathrm{mg} / \mathrm{mL}$; D, $0.25 \mathrm{mg} / \mathrm{mL}$; , control; - ${ }^{*}$, No inhibition.

$\mathrm{FI}-1004)$ 에 의거하여 $1 \mathrm{~L}$ 의 시험용기에 초기농도 $500 \mathrm{ppm}$ 의 암모 니아 가스를 채운 후 $30 \mathrm{~min}$ 간격으로 $2 \mathrm{~h}$ 동안 측정하였다. 시료가 들어있지 않은 용기의 암모니아 가스농도 $(\mathrm{Cb})$ 와 시료를 넣은 용기의 암모니아 가스농도 $(\mathrm{Cs})$ 를 비교하여 소취율(deodorization rate, DR) 을 계산하였다.

\section{5. 통계처리}

본 연구의 모든 실험 결과는 3 회 이상 반복하여 평균값으로 나타 내었으며, 통계학적 유의성은 Student's $t$-test로 분석하였으며, $p$ value가 0.05 미만일 경우 통계적으로 유의한 것으로 판정하였다 $\left({ }^{*} p<0.05,{ }^{* *} p<0.01\right)$.

\section{Results and Discussion}

\section{1. 생강 부위별 추출물의 항균효과}

가. S. aureus에 대한 항균효과

피부의 염증성 질환에 대표적인 피부 상재균 중 $S$, aureus는 아토 피 피부염에 요인이 되어 피부 모공 또는 상처에 화농을 유발 시키며 악화시키는 원인이 된다(Kim \& Lee, 2019). 생강 부위별 추출물의 S. aureus에 대한 항균효과를 확인하기 위해 균의 생육저해환인 clear zone $(\mathrm{mm})$ 을 측정한 결과 Figure 1과 같이 나타났다. 생강 잎, 줄기, 뿌리 추출물 $0.25-5 \mathrm{mg} / \mathrm{mL}$ 농도에서 생강 잎 추출물은 $2,2,3,3$ $\mathrm{mm}$ 의 clear zone이 확인되었으며, 줄기 추출물은 $0.25 \mathrm{mg} / \mathrm{mL}$ 농도 에서는 clear zone이 확인되지 않았으며, $0.5-5 \mathrm{mg} / \mathrm{mL}$ 농도에서 각 각 $2,3,3 \mathrm{~mm}$ 의 clear zone이 확인 되었다. 뿌리 추출물도 $0.25 \mathrm{mg} /$ $\mathrm{mL}$ 농도에서는 clear zone이 확인되지 않았으며, $0.5-5 \mathrm{mg} / \mathrm{mL}$ 농 도에서 각각 $1,1,2 \mathrm{~mm}$ 의 clear zone이 확인되었다. 생강 잎 추출물 이 $S$. aureus에 대해 가장 높은 항균효과가 확인되었다.
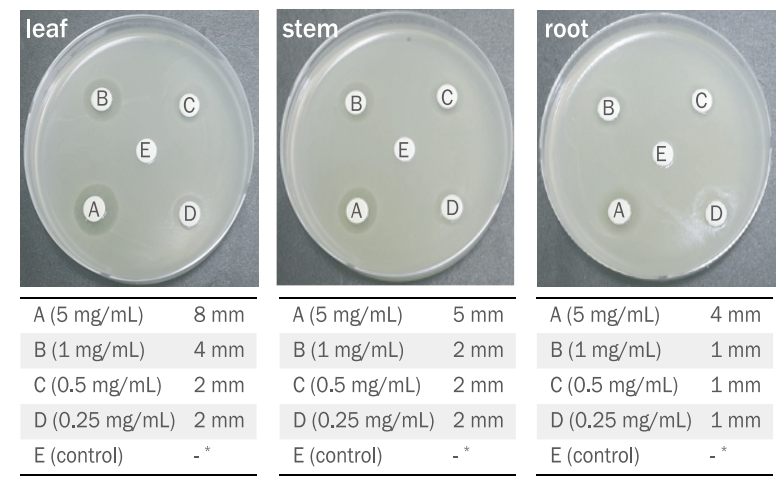

Figure 2. Clear zone diameters of leaf, stem, and root extracts of Zingiber officinal on the growth of Staphylococcus epidermidis.

A, $5 \mathrm{mg} / \mathrm{mL}$; B, $1 \mathrm{mg} / \mathrm{mL}$; C, $0.5 \mathrm{mg} / \mathrm{mL}$; D, $0.25 \mathrm{mg} / \mathrm{mL}$; , control; - ", No inhibition.

\section{나. S. epidermidis에 대한 항균효과}

S. epidermidis는 호기성으로 외모낭 또는 모낭의 중간에서 생장 하고 정상인 피부에서도 관찰되지만 모공이 막힌 경우 급격하게 증식 하여 염증을 유발하는 것으로 알려져 있다. 피부가 염증에 노출될 경 우 미생물 침입을 방어하는 방어 기작 또한 약해지고 2차적인 피부장 벽의 약화를 발생시키고, 또 다른 미생물 감염의 원인이 되어 악순환 이 반복된다(Kim et al., 2013b; Lee et al., 2016a)

생강 부위별 추출물의 $S$ epidermidis에 대한 항균효과를 확인하 기 위해 균의 생육저해환인 clear zone (mm)을 측정한 결과 Figure 2 와 같이 나타났다. 생강 잎, 줄기, 뿌리 추출물은 $0.25-5 \mathrm{mg} / \mathrm{mL}$ 농도에서 생강 잎 추출물은 $2,2,4,8 \mathrm{~mm}$ 의 clear zone이 확인되었 으며, 줄기 추출물은 $2,2,2,5 \mathrm{~mm}$ 의 clear zone이 확인 되었다. 뿌 리 추출물도 $1,1,1,4 \mathrm{~m}$ 의 clear zone이 확인되었다. 생강 잎 추출 물은 Choi \& Ohk (2017)의 그라비올라 잎 추출물 보다 항균효과가 높게 확인되었다.

\section{다. P. acnes에 대한 항균효과}

여드름은 주로 사춘기에서 발생하는 모낭피지선의 만성 염증성 질환으로 면포, 구진 및 결절을 형성하고 심하면 흉터를 남길 수 있 는 만성 염증성 피부 질환으로 주로 사춘기와 젊은 연령층에서 나타 난다. 여드름의 정확한 원인은 알려져 있지 않지만 크게 4 가지 즉 모 공의 과각화, 피지 분비 증가, 여드름 균의 증식, 모낭 부위의 염증 발생 등이 여드름 발생의 주요 원인으로 지목되고 있다(Lee et al., 2016b; Lee \& Son, 2018). P. acnes는 통성 혐기성 그람 양성균이 자 여드름의 주요한 원인균으로 알려져 있으며 피지를 주 영양원으로 한다. 모낭의 안쪽에서 성장하고, 청소년기 호르몬과 피지 샘 분비가 활발해지면 더욱 증식하며, 리파아제(lipase)를 분비하여 많은 양의 글리세롤과 지방산을 생성하여 모낭 벽을 직접 자극하고 진피 내로 들어가 염증을 일으켜서 여드름이 발생된다(Kim et al ., 2013a). 

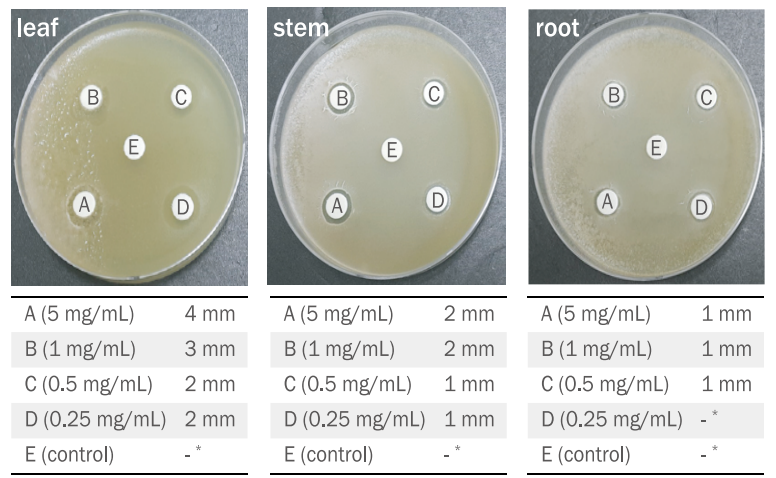

Figure 3. Clear zone diameters of leaf, stem, and root extracts of Zingiber officinal on the growth of Propionibacterium acnes.

A, , $5 \mathrm{mg} / \mathrm{mL}$; B, $1 \mathrm{mg} / \mathrm{mL}$; C, $0.5 \mathrm{mg} / \mathrm{mL}$; D, $0.25 \mathrm{mg} / \mathrm{mL}$; , control; - " , No inhibition.
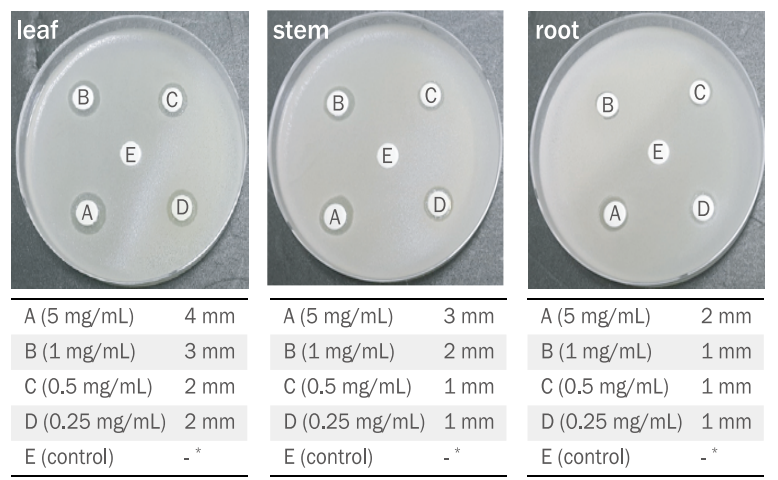

Figure 5. Clear zone diameters of leaf, stem, and root extracts of Zingiber officinal on the growth of Malassezia furfur.

A, $5 \mathrm{mg} / \mathrm{mL}$; B, $1 \mathrm{mg} / \mathrm{mL}$; C, $0.5 \mathrm{mg} / \mathrm{mL}$; D, $0.25 \mathrm{mg} / \mathrm{mL}$; E, control; - " , No inhibition.

생강 부위별 추출물의 $P$. acnes에 대한 항균효과를 확인하기 위 해 균의 생육저해환인 clear zone $(\mathrm{mm})$ 을 측정한 결과 Figure 3 과 같이 나타났다. 생강 잎, 줄기, 뿌리 추출물은 $0.25-5 \mathrm{mg} / \mathrm{mL}$ 농도 에서 생강 잎 추출물은 $2,2,3,4 \mathrm{~mm}$ 의 clear zone이 확인되었으 며, 줄기 추출물은 $1,1,2,3 \mathrm{~mm}$ 의 clear zone이 확인되었다. 뿌리 추출물은 $0.25 \mathrm{mg} / \mathrm{mL}$ 농도에서는 항균효과가 확인되지 않았으며 $0.5-5 \mathrm{mg} / \mathrm{mL}$ 농도에서 각각 $1,1,1 \mathrm{~mm}$ 의 clear zone이 확인되 었다. 생강 잎 추출물이 P. acnes에 대해 가장 높은 항균효과가 확 인되었다.

\section{라. P. ovale에 대한 항균효과}

탈모와 함께 비듬(dandruff)은 두피 피지선의 분비물과 함께 말 라붙어 생긴 각질 형태의 덩어리로, 심한 경우 붉어지고 가려움과 염증을 수반하는 지루성 피부염(seborrheic dermatitis)으로 까지 진 행될 수 있으며, 비듬이 심할수록 자연 탈모량이 증가되는 경향이

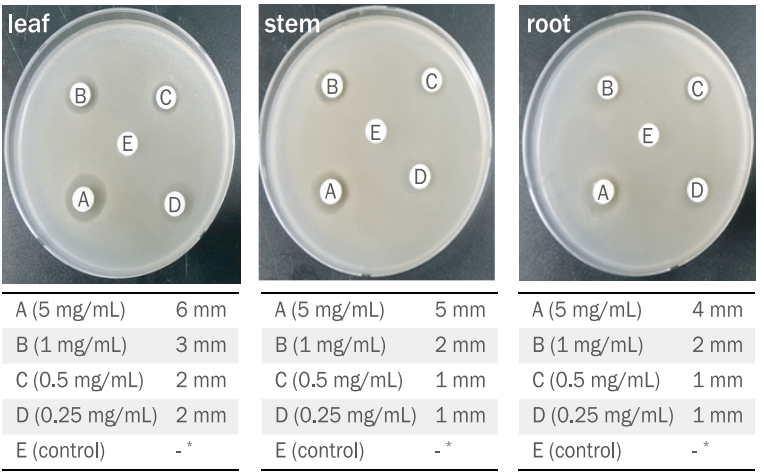

Figure 4. Clear zone diameters of leaf, stem, and root extracts of Zingiber officinal on the growth of Pityrosporum ovale.

A, $5 \mathrm{mg} / \mathrm{mL}$; B, $1 \mathrm{mg} / \mathrm{mL}$; C, $0.5 \mathrm{mg} / \mathrm{mL}$; D, $0.25 \mathrm{mg} / \mathrm{mL}$; , control.
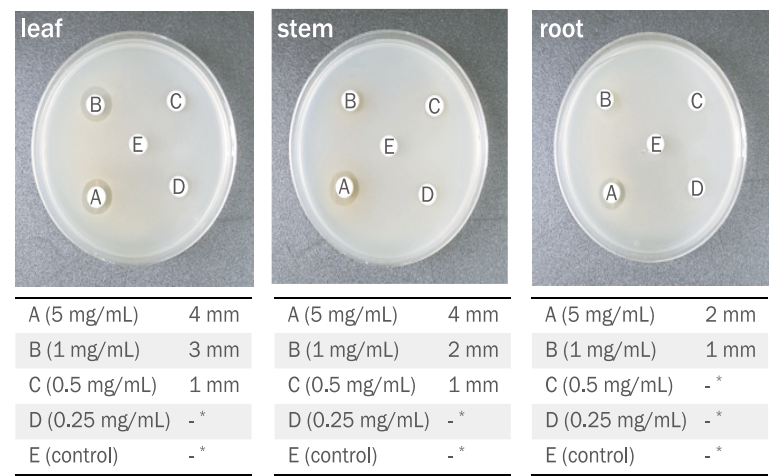

Figure 6. Clear zone diameters of leaf, stem, and root extracts of Zingiber officinal on the growth of Candida albicans.

A, $5 \mathrm{mg} / \mathrm{mL}$; B, $1 \mathrm{mg} / \mathrm{mL}$; C, $0.5 \mathrm{mg} / \mathrm{mL}$; D, $0.25 \mathrm{mg} / \mathrm{mL}$; , control; - ", No inhibition.

있다. 비듬 발생의 근본적인 원인은 내분비 호르몬의 불균형, 영양 상태의 불균형, 스트레스, 두피세포의 지나친 증식, 곰팡이 균의 일 종인 비듬균(Pityrosporum ovale, P. ovale)의 증식 및 활성 증대, 대기 오염에 의한 염증 등과 같은 여러 요인들의 복합적인 영향에 의한 것으로 알려져 있다(Lee et al,. 2010; Oh et al., 2014).

생강 부위별 추출물의 $P$. ovale에 대한 항균효과를 확인하기 위해 균의 생육저해환인 clear zone $(\mathrm{mm})$ 을 측정한 결과 Figure 4 와 같 이 나타났다. $0.25-5 \mathrm{mg} / \mathrm{mL}$ 에서 생강 잎 추출물은 $2,2,3,6 \mathrm{~mm}$ 의 clear zone이 확인되었고, 줄기 추출물은 $1,1,2,5 \mathrm{~mm}$ 의 clear zone이 확인되었다. 뿌리 추출물은 $1,1,2,4 \mathrm{~mm}$ 의 clear zone이 확인되었다.

\section{마. Malassezia furfur에 대한 항균효과}

비듬은 피부의 정상 세균 중 하나인 피부사상균 Malassezia furfur (M. furfu)라는 곰팡이의 과다 증식이 주요 원인이 되기도 한 

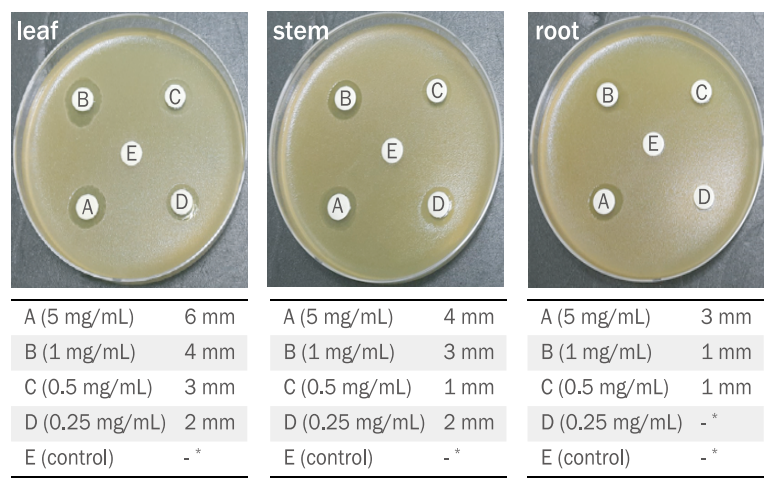

Figure 7. Clear zone diameters of leaf, stem, and root extracts of Zingiber officinal on the growth of Trichophyton mentagrophytes. A, $5 \mathrm{mg} / \mathrm{mL}$; B, $1 \mathrm{mg} / \mathrm{mL}$; C, $0.5 \mathrm{mg} / \mathrm{mL}$; D, $0.25 \mathrm{mg} / \mathrm{mL}$; , control; - " , No inhibition.

다. M. furfu이 원인으로 생기는 비듬증은 두피가 건조해지면서 각 질이 일어나 심한 가려움증을 수반하는 건성 지루를 유발하기도 한 다. 두피가 심한 통증이나 가려움증 또는 염증이나 홍반을 동반하는 경우에는 비듬균이 원인이 되어 나타나는 증상들로 반드시 비듬균 의 성장을 억제해야 한다(An et al., 2013).

생강 부위별 추출물의 $M$. furfur에 대한 항균효과를 확인하기 위 해 균의 생육저해환인 clear zone $(\mathrm{mm})$ 을 측정한 결과 Figure 5 와 같이 나타났다. 생강 잎, 줄기, 뿌리 추출물 $0.25-5 \mathrm{mg} / \mathrm{mL}$ 농도에 서 생강 잎 추출물은 $2,2,3,4 \mathrm{~mm}$ 의 clear zone이 확인되었고, 줄 기 추출물은 1, 1, 2, $3 \mathrm{~mm}$ 의 clear zone이 확인되었다. 뿌리 추출 물은 $1,1,1,2 \mathrm{~mm}$ 의 clear zone이 확인되었다.

\section{바. C. albicans에 대한 항균효과}

C. albicans는 효모균 중에 약 85-90\%의 감염을 일으키고, 인 체에 면역력이 저하되면 기회성 감염을 유발하며, 정상조직 피부에 약 $20 \%$ 정도 존재한다. 또한 여성의 질 내벽을 감염시키는 경우가 대다수이며 질염 중 약 20-25\% 정도를 차지하고 있다(Lee et al., 2014).

생강 잎, 줄기, 뿌리 추출물의 $C$. albicans에 대한 항균효과를 확 인하기 위해 균의 생육저해환인 clear zone $(\mathrm{mm})$ 을 측정한 결과 Figure 6 과 같이 나타났다. 생강 잎, 줄기, 뿌리 추출물은 $0.25 \mathrm{mg} /$ $\mathrm{mL}$ 농도에서는 clear zone이 확인되지 않았으며, $0.5-5 \mathrm{mg} / \mathrm{mL}$ 농도에서 생강 잎 추출물은 $1,3,4 \mathrm{~mm}$ clear zone 확인되었으며, 줄기 추출물은 $1,2,4 \mathrm{~mm}$ clear zone 확인되었으며, 뿌리 추출물 은 $0.5 \mathrm{mg} / \mathrm{mL}$ 농도에서도 clear zone이 확인되지 않았으며, 1-5 $\mathrm{mg} / \mathrm{mL}$ 농도에서 $1,2 \mathrm{~mm}$ 의 clear zone이 확인되었다.

\section{사. T. mentagrophytes에 대한 항균효과}

아토피 피부질환 환자의 경우 피부장벽 기능의 손상으로 감염성

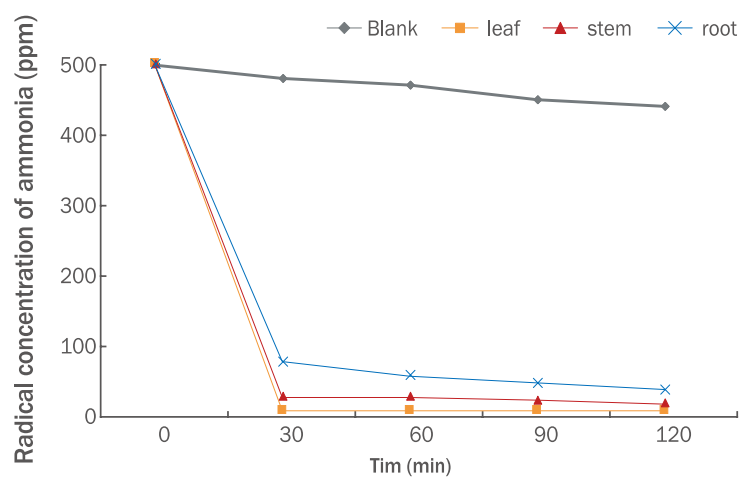

Figure 8. Changes in the ammonia concentration of leaf, stem, and root extracts of Zingiber officinal.

질환의 동반이 흔해 표재성 진균 감염의 발생율이 높다고 보고되었 고, 알레르기를 일으키는 곰팡이에 의해 아토피 피부질환이 악화된 다고 보고된 바 있다. 이러한 연구를 바탕으로 아토피 피부질환 개 선을 위해서 표재성 진균에 대한 항진균 활성 연구가 필요하다(Kim et al., 2012).

T. mentagrophytes은 표재성 진균으로 무좀의 주 원인균으로도 알려져 있다. 주로 고온 다습한 여름철에 손과 발에 발생하는 피부 병이나, 생활환경, 직업, 면역상태 및 무좀균의 종류 등에 따라 신 체의 어느 부위에나 발생이 가능한 것으로 알려져 있다(Ha et al., 2009).

생강 잎, 줄기, 뿌리 추출물의 T. mentagrophytes에 대한 생육저 해환인 clear zone $(\mathrm{mm})$ 을 측정한 결과 Figure 7과 같이 나타났다. 생강 잎, 줄기, 뿌리 추출물 $0.25-5 \mathrm{mg} / \mathrm{mL}$ 농도에서 생강 잎 추 출물은 $2,3,4,6 \mathrm{~mm}$ 의 clear zone이 확인되었으며, 줄기 추출물 은 2, $1,3,4 \mathrm{~mm}$ 의 clear zone이 확인되었다. 뿌리 추출물은 0.25 $\mathrm{mg} / \mathrm{mL}$ 농도에서 clear zone이 확인되지 않았으며, $0.5-5 \mathrm{mg} / \mathrm{mL}$ 농도에서 $1,1,3 \mathrm{~mm}$ 의 clear zone이 확인되었다.

\section{2. 생강 부위별 추출물의 소취효과}

악취는 인간에게 정신적, 생리학적 스트레스를 유발시켜 메스꺼 움, 두통, 식욕감퇴, 호흡곤란 및 알레르기 현상으로 등으로 인간 의 후각시스템을 자극할 뿐 만 아니라 불쾌감을 유발하는 감각 공 해 물질로 집중력, 판단력 및 활동에까지 영향을 미친다(Ryu et al., 2013).

인체의 체취 소멸 속도와 암모니아 가스의 소멸속도는 비슷한 것 으로 추정되어서 암모니아가스를 악취평가 기준으로 생강 부위별 추출물의 소취효과를 측정하였다. 생강 잎, 줄기, 뿌리 추출물을 처 리하여 시간에 따른 ammonia 농도 변화를 측정한 값은 Figure 8 와 같으며, 이를 소취율로 계산한 값은 Figure 9 과 같다. 밀폐된 삼 각플라스크에 악취를 유발시킨 뒤 생강 잎, 줄기, 뿌리 추출물을 주 입한 후 $30 \mathrm{~min}$ 간격으로 $120 \mathrm{~min}$ 측정한 결과, 생강 잎 추출물은 


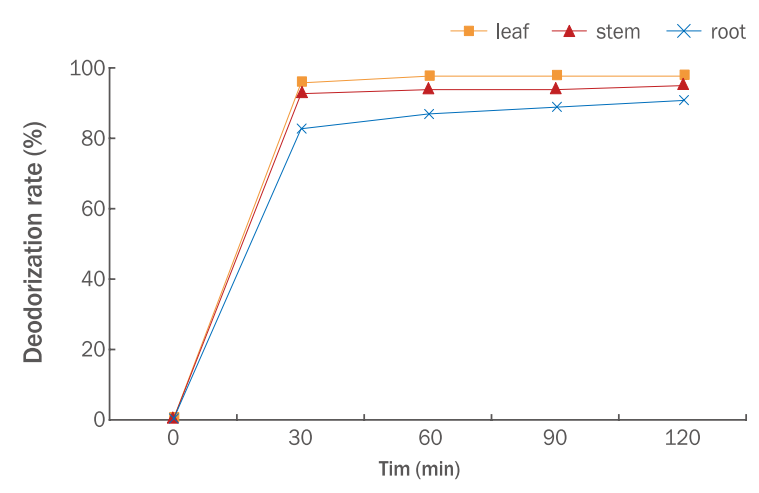

Figure 9. Deodorization rate of ammonia of leaf, stem, and root extracts of Zingiber officinal.

$30 \mathrm{~min}$ 부터 $96 \%$ 의 소취효과를 나타냈으며, 줄기 추출물은 $30 \mathrm{~min}$ 에는 $93 \%$ 의 소취효과가 나타났으며, 뿌리 추출물은 $83 \%$ 의 소취효 과가 나타났다. 시간이 경과함에 따라 점차 증가하여 $120 \mathrm{~min}$ 에는 생강 잎 추출물은 $98 \%$, 줄기 추출물은 $95 \%$, 뿌리 추출물은 $91 \%$ 소 취효과를 보였다. 생강 잎 추출물이 가장 높은 소취효과가 확인되었 다. 이상의 결과는 잣나무 정유(Hwang et al., 2014)의 $74.77 \%$ 소 취력보다 높게 확인되었다.

\section{Conclusion}

생강 잎, 줄기, 뿌리 추출물의 피부상재균에 대한 항균효과 및 암 모니아에 대하 소취능을 평가하여 항균소재 및 기능성 향장품 소재 로서의 가능성을 확인한 결과 다음과 같다.

생강 부위별 추출물 항균효과 측정 결과 $S$. aureus에 대한 항균 효과는 $5 \mathrm{mg} / \mathrm{mL}$ 농도에서 생강 잎 추출물은 $3 \mathrm{~mm}$, 줄기 추출물 은 $3 \mathrm{~mm}$, 뿌리 추출물은 $2 \mathrm{~mm}$ 의 clear zone이 확인되었다. $S$. epidermidis에 대한 항균효과 는 $5 \mathrm{mg} / \mathrm{mL}$ 농도에서 생강 잎 추출 물은 $8 \mathrm{~mm}$, 줄기 추출물은 $5 \mathrm{~mm}$, 뿌리 추출물은 $4 \mathrm{~mm}$ 의 clear zone이 확인되었다. 여드름의 원인균인 P. acnes에 대한 항균효과 를 측정한 결과, $5 \mathrm{mg} / \mathrm{mL}$ 농도에서 생강 잎 추출물은 $4 \mathrm{~mm}$, 줄 기 추출물은 $3 \mathrm{~mm}$ 뿌리 추출물은 $1 \mathrm{~mm}$ 의 clear zone이 확인되었 다. P. ovale에 대한 항균효과를 측정한 결과는 $5 \mathrm{mg} / \mathrm{mL}$ 농도에 서 생강 잎 추출물은 $6 \mathrm{~mm}$, 줄기 추출물은 $5 \mathrm{~mm}$, 뿌리 추출물은 4 $\mathrm{mm}$ 의 clear zone이 확인되었다. $M$. furfur에 대한 항균효과를 측 정한 결과 $5 \mathrm{mg} / \mathrm{mL}$ 농도에서 생강 잎 추출물은 $4 \mathrm{~mm}$, 줄기 추출 물은 $3 \mathrm{~mm}$, 뿌리 추출물은 $2 \mathrm{~mm}$ 의 clear zone이 확인되었다. $C$. albicans에 대한 항균효과를 측정한 결과 $5 \mathrm{mg} / \mathrm{mL}$ 농도에서 생강 잎 추출물은 $4 \mathrm{~mm}$, 줄기 추출물은 $3 \mathrm{~mm}$ clear zone 확인되었으 며, 뿌리 추출물은 $2 \mathrm{~mm}$ 의 clear zone이 확인되었다. 마지막으로 $T$. mentagrophytes에 대한 항균효과를 측정한 결과 $5 \mathrm{mg} / \mathrm{mL}$ 농도에 서 생강 잎 추출물은 $6 \mathrm{~mm}$, 줄기 추출물은 $4 \mathrm{~mm}$, 뿌리 추출물은 3 $\mathrm{mm}$ 의 clear zone이 확인되었다.

암모니아에 대한 생강 부위별 추출물의 소취효과를 측정한 결과 30 분부터 생강 잎 추출물은 $96 \%$, 줄기 추출물은 $93 \%$, 뿌리 추출 물은 $83 \%$ 의 소취효과가 나타났으며, 120 분에는 생강 잎 추출물은 $98 \%$, 줄기 추출물은 $95 \%$, 뿌리 추출물은 $91 \%$ 의 소취효과가 확인되 었다.

본 연구 결과 생강 부위별 추출물 중 잎 추출물이 7종의 피부상재 균에 대한 항균효과도 가장 우수하였으며, 소취효과도 생강 잎 추출 물이 가장 높이 확인되어 항균소재 및 기능성 향장품 소재로서의 가 능성을 확인하였다.

\section{Author's contribution}

YSL, YJK and MJR contributed equally to this work. YSL, YJK and MJR designed all experimental investigations and developed a process to check the possibilities with cosmetic materials. YSL, YJK designed and supported the experiment, participated in the experiment, and MJR wrote the manuscript with the help of YSL, YJK.

\section{Author details}

Young Suk Lee (Director), Su Mi Beauty Salon, Beommuldong, Suseong-gu, Daegu 1330-1, Korea; Young Ju Kang (Representation), Jusighoesa Gat-eunsaeng-gag, 41 Anmyeon-ro, Dong-gu Daegu 4111, Korea; Min Jeong Ryu (Professor), Department of Cosmetology Science, Nambu University, 23 advanced Jungang-ro, Gwangsan-gu, Gwangju 62271, Korea

\section{References}

An GS, Hwang IC, Kim HK. Antimicrobial activities against Malassezia furfur in the herb extracts which contain the cultured Korean wild ginseng. Journal of Health and Beauty, 7: 51-57, 2013.

Ahn JY, Kim JH, Kwon SU, Kim DK, Lee KS, Lee YM. Antimicrobial, antiperspirant and deodorant effect of herbal extract mixtures including Schisandra chinensis. Journal of Physiology \& Pathology in Korean Medicine, 26: 53-58, 2012.

Choi JH, Ohk SH. Antibacterial activity of Graviola extract to 
inhibit the Staphylococcus epidermidis. Journal of the Korea Academia-Industrial cooperation Society, 18: 667673, 2017.

Guon TE, Chung HS. Effect of Zingiber officinale roscoe extract on antioxidant and apoptosis in A2058 human melanoma cells. Journal of Physiology \& Pathology in Korean Medicine, 26: 207-214, 2016.

Han EJ, Kim JM. Quality characteristics of Yanggaeng prepared with different amounts of ginger powder. Journal of the East Asian Society of Dietary Life, 20: 360366, 2011.

Ha YM, Lee BB, Bae HJ, Je KM, Kim SR, Choi JS, Choi IS. Anti-microbial activity of grapefruit seed extract and processed sulfur solution against human skin pathogens. Journal of Life Science, 19: 94-100, 2009.

Hwang HJ, Yu JS, Lee HY, Kwon DJ, Han W, Heo SI, Kim SY. Evaluations on deodorization effect and anti-oral microbial activity of essential oil from Pinus koraiensis. Korean Journal of Plant Resources, 27: 1-10, 2014.

Hwang EG, Yi JK, Ha JJ, Oh DY, Kim BK. Physiochemical properties of pork jerky supplemented with ginger and ginseng powders during curing. Journal of Agriculture \& Life Science, 49: 173-187, 2015.

Jung KG, Park CS. Antioxidative and antimicrobial activities of juice from garlic, ginger, and onion. Korean Journal of Food Preservation, 20: 134-139, 2013.

Kim EH, Jang YA, Kim SB, Kim HH, Lee JT. Antimicrobial, antifungal effect and safety verification using BCOP assay of extracts from Coptis chinensis. Applied Biological Chemistry, 61: 297-304, 2018.

Kim JM, Lee KS. Quality characteristics of white pan bread added with ginger extract. Culinary Science \& Hospitality Research, 25: 86-97, 2019.

Kim YJ, So YJ. Effect of nettle extract on antibacterial property and scalp improvement. Journal of the Korean Society of Cosmetology, 99: 976-981, 2016.

Kim YD, Kim YM, Mo EK. Antibacterial, antioxidant, and antiaging effects of the ethanol extract of Dolnamul (Sedum sarmentosum) and the production of the oil in water cream. Journal of the Society of Cosmetic Scientists of Korea, 43: 211-221, 2017.

Kim SE, Lee IC. Study on the bioactive characteristics of Spergularia marina L. Griseb extract as cosmatic raw material. Journal of the Korean Society of Beauty and
Art, 20: 59-71, 2019.

Kim SH, Lee SY, Hong SY, Jeong HS. Park MJ, Choi IG. Antifungal activity of essential oil from Cryptomeria japonica against dermatophytic fungi. Journal of the Korean Wood Science and Technology, 40: 276-286, 2012.

Kim SJ, Kim Sh, Lim YI, Kim YG, Park KY. Inhibitory effects of ginger and Beopje ginger on DSS-induced colitis in mice. Journal of the Korean Society of Food Science and Nutrition, 43: 477-484, 2014.

Kim SJ, Lee JY, Ju JS, Lee YH. Inhibitory effects of ginger (Zingiber officinale Roscoe) ethanol extract on benign prostatic hyperplasia. Journal of the Korean Society of Food Science and Nutrition, 49: 425-432, 2020.

Kim SS, Hyun JM, Kim KS, Park JK, Park SM, Choi YH. Influence of essential oil in 'Shiranuhi' immature fruit on antioxidant and antimicrobial activities. Korean Journal of Medicinal Crop Science, 21: 493-497, 2013a.

Kim YS, Jeong YH, Kim KY. Anti-oxidative activities and melanin synthesis inhibition of smilax china folium ethanol extract. Journal of the Korean Society of Cosmetology, 19: 557-567, 2013b

Ko MO, Kang HJ, Hwang JH, Yang KW. Screening of the antibacterial effects by ethanol extracts from natural plant in Jeju against Propionibacterium acnes. Journal of the Society of Cosmetic Scientists of Korea, 44: 59-66, 2018.

Lee AR, Roh SS, Kim HK. Anti-microbial activity and antiinflammatory effects of fucoidan extracts. Asian Journal of Beauty and Cosmetology, 16: 191-200, 2018.

Lee BE, Yang JC, Kim BA. A study of antioxidative and antimicrobial effects of coffee residue extracts. Journal of the Korean Applied Science and Technology, 33: 606-613, 2016a.

Lee EJ, Yang SA, Choi HD, Im HG, Whang K, Lee IS. Comparison of gingerols in various fractions and the antioxidant effects of supercritical fluid extracts from ginger. Korean Journal of Food Science and Technology, 43: 469-474, 2011.

Lee HJ, Moon JH, Lee WM, Lee SG, Park DK, Yoon MK. Antioxidant enzymes and antimicrobial activities in sponge gourds. Horticultural Science \& Technology, 32: 702-709, 2014.

Lee IH, Kim MJ, Choi JH, Choi SH. Antifungal effect of 
bilobalide and ginkgolide extracted from leaves of Ginkgo biloba against Pityrosporum ovale. KSBB Journal, 25: 173-178, 2010.

Lee KH, Shin ES, Sim EJ, Bae YJ. Comparison of antioxidant and antimicrobial activities of Fingerroot (Boesenbergia pandura) and ginger (Zingiber officinale Roscoe). The Korean Journal of Food Science and Nutrition, 33: 105110, 2020.

Lee JY, Son HJ. Trends in the efficacy and safety of ingredients in acne skin treatments. Asian Journal of Beauty and Cosmetology, 16: 449-463, 2018.

Lee SJ, Lee EH, Shin JH, Kim SS, Kim NK, Choi E, Seo SR. Eucalyptus globulus extracts inhibit Propionibacterium acnes-induced inflammation signaling. Korean Journal of Microbiology, 52: 421-427, 2016b.

Lee SM. Quality characteristics of apple jam added with ginger. Culinary Science and Hospitality Research, 20: 79-
88, 2014.

Lee YS, Ryu MJ. Antioxidant effects of Cinnamomum cassia Bark extract and its effectiveness as a cosmetics ingredient. Asian Journal of Beauty and Cosmetology, 17: 69-80, 2019.

Lim MH, Hong SJ. Availability of Opuntia ficus-indica var. saboten stem extracts as a natural preservative. Asian Journal of Beauty and Cosmetology, 14: 449-461. 2016.

Oh JY, Lee BS, Kim YC. Hair growth promotion effect and anti-bacterial activity against Pityrosporum ovale of peppermint oil. Journal of Investigative Cosmetology, 10: 261-269, 2014.

Ryu H, Ko WH, Kim JW, Kim SR, Kim MK. Electroencephalography activities influenced by classroom smells of male high school. Korean Journal of the Sciences of Emotion \& Sensibility, 16: 387-396, 2013. 


\section{국문초록}

\section{생강 부위별 추출물의 항균효과 및 소취효과}

이영숙 ${ }^{1}$, 강영주 ${ }^{2}$, 유민정 ${ }^{*}$

${ }^{1}$ 수미미용실, 대구, 한국

${ }^{2}$ (주)같은 생각, 대구, 한국

${ }^{3}$ 남부대학교 향장미용학과, 광주, 한국

목적: 생강 부위별 추출물의 피부 상재균에 대한 항균효과 및 암모니아에 대하 소취능을 평가하여 항균소재 및 기능성 향장품 소재 로서의 가능성을 예측하고자 한다. 방법: 피부 상재균에 대한 항균효과는 paper disc 방법으로 측정하였다. 소취효과 측정은 암모 니아 가스 제거 실험을 하였다. 결과: 생강 부위별(잎, 줄기, 뿌리) 추출물 항균효과 측정 결과 $S$. aureus에 대한 항균효과는 $5 \mathrm{mg} /$ $\mathrm{mL}$ 농도에서 각각 $3 \mathrm{~mm}, 3 \mathrm{~mm}, 2 \mathrm{~mm}$ 의 clear zone이 확인되었다. S. epidermidis에 대한 항균효과는 각각 $8 \mathrm{~mm}, 5 \mathrm{~mm}, 4 \mathrm{~mm}$ 의 clear zone이 확인되었다. 여드름의 원인균인 $P$. acnes에서는 각각 $4 \mathrm{~mm}, 3 \mathrm{~mm}, 1 \mathrm{~mm}$ 의 clear zone이 확인되었다. $P$. ovale에 서는 각각 $6 \mathrm{~mm}, 5 \mathrm{~mm}, 4 \mathrm{~mm}$ 의 clear zone이 확인되었다. $M$. furfur에서는 각각 $4 \mathrm{~mm}, 3 \mathrm{~mm}, 2 \mathrm{~mm}$ 의 clear zone이 확인되었다. C. albicans에서는 각각 $4 \mathrm{~mm}, 3 \mathrm{~mm}, 2 \mathrm{~mm}$ 의 clear zone이 확인되었다. 마지막으로 T. mentagrophytes에 대한 항균효과를 측정 한 결과 $5 \mathrm{mg} / \mathrm{mL}$ 농도에서 생강 잎 추출물은 $6 \mathrm{~mm}$, 줄기 추출물은 $4 \mathrm{~mm}$, 뿌리 추출물은 $3 \mathrm{~mm}$ 의 clear zone이 확인되었다. 암모 니아에 대한 소취효과를 측정한 결과 $120 \mathrm{~min}$ 에는 생강 잎 추출물은 $98 \%$, 줄기 추출물은 $95 \%$, 뿌리 추출물은 $91 \%$ 의 소취효과가 확인되었다. 결론: 생강 부위별 추출물 중 잎 추출물이 7종의 피부상재균에 대한 항균효과도 가장 우수하였으며, 소취효과도 생강 잎 추출물이 가장 높은 효과가 확인되어 항균소재 및 기능성 향장품 소재로서의 가능성을 확인하였다.

핵심어: 생강, 항균효과, 소취효과, 암모니아, 화장품

\section{참고문헌}

고미옥, 강희주, 황준호, 양경월. Propionibacterium acnes에 대한 제주 자생식물 에탄올 추출물의 항균효과 검색. 대한 화장품학회지, 44: $59-66,2018$.

권태은, 정하숙. 생강(Zingiber officinale Roscoe) 추출물의 항산화 및 A2058 흑색종세포 사멸 효과. 동아생리병리학회 지, 26: 207-214, 2016.

김소은, 이인철. 화장품 소재로서 세발나물 추출물의 생리활성 연구. 한국인체미용예술학회지, 20: 59-71, 2019.

김상숙, 현주미, 김광식, 박경진, 박석만, 최영훈. 부지화 미숙과 에센셜 오일의 항산화 및 항균 활성 효과. 한국약용작물 학회지, 21: 493-497, 2013.

김신정, 김소희, 임양이, 김용규, 박건영. 생강과 법제생강의 DSS (Dextran Sulfate Sodium)로 유도된 마우스의 대장염 억제 효과. 한국식품영양과학회지, 43: 477-484, 2014.

김선홍, 이수연, 홍창영, 정한섭, 박미진, 최인규. 삼나무 정유의 표재성 진균에 대한 항진균 활성. 목재공학, $40: 276-$ $286,2012$.

김수정, 이정윤, 주정선, 이유현. 생강(Zingiber officinale Roscoe) 에탄올 추출물의 전립선비대 억제 효과. 한국식품영양 과학회지, 49: 425-432, 2020.

김윤주, 소영진. 네틀 추출물의 항균성 및 두피개선효과. 한국미용학회지. 99: 976-981, 2016.

김영대, 김영민, 모은경. 돌나물(Sedum sarmentosum) 에탄올 추출물의 항균, 항산화, 항노화 효과와 수중유적형 크림의

제조. 대한화장품학회지, 43: 211-221, 2017.

김은희, 장영아, 김솔비, 김한혁, 이진태. 황련(Coptis chinensis) 추출물의 항균, 항진균 효과와 $\mathrm{BCOP}$ 분석을 이용한 안 
전성 검증. Applied Biological Chemistry, 61: 297-304, 2018.

김용숙, 윤영한, 이현숙, 김기영. 천연화장품 소재 탐색을 위한 명감나무잎 추출물과 분획물이 피부 균주에 대한 항균활성

조사. 한국미용학회지, 19: 557-564, 2013.

김지민, 이광석. 생강즙을 첨가한 식빵의 품질 특성. 한국조리학회지, 25: 86-97, 2019.

류현, 고우형, 김정우, 김수린, 김민경. 남자고등학교 교실냄새에 대한 뇌파반응. 감성과학회지, 16: 387-396, 2013.

이경행, 신은주, 심은주, 배윤정. 핑거루트(Boesenbergia pandura)와 생강(Zingiber oficinale Rosecoe)의 항산화 및 항

균 활성 비교. 한국식품영향학회지, 33: 105-110, 2020.

이병은, 양재찬, 김보애. 커피 부산물의 항산화와 항균력에 관한 연구. 한국유화학회지, 33: 606-613, 2016.

이아름, 노성수, 김현경. 후코이단 추출물의 항균 및 항산화 효과. 아시안뷰티화장품학회지, 16: 191-200, 2018.

이은주, 양선아, 최희돈, 임효권, 황기, 이인선. 생강분획의 gingerols 분석 및 초임계 추출물의 항산화 효과. 한국식품과

학회지, 43: 469-474, 2011.

이영숙, 유민정. 계피 추출물의 항산화 효과 및 화장품소재의 응용. 아시안뷰티화장품학술지, 17: 69-80, 2019.

이솔지, 이은혜, 신진학, 김선숙, 김남경, 최은미, 서수련. 유칼립투스 추출물의 Propionibacterium acnes에 의해 유도되

는 염증반응 억제 효과. 미생물학회지, 52: 421-427, 2016.

이승민. 생강을 첨가한 사과잼의 품질특성에 관한 연구. 한국조리학회지, 20: 79-88, 2014.

이주연, 손효정. 여드름 피부에 효능 및 안정성을 가진 성분의 연구동향. 아시안뷰티화장품학술지, 16: 449-463, 2018.

이희주, 문지혜, 이우문, 이상규, 박동금, 윤무경. 수세미 오이의 항산화 효소 및 항균 활성 검증. 원예과학기술지, 32 :

702-709, 2014.

이인화, 김미진, 최준호, 김치현, 최승현. 비듬유발균(Pityrosporum ovale)에 대한 은행잎으로부터 추출한 Ginkgolide 및

Bilobalide의 항진균 효과. KSBB Journal, 25: 173-178, 2010.

임미혜, 홍세정. 백년초 줄기 추출물의 화장품용 천연 방부제로서의 활용성. 아시안뷰티화장품학술지, $14: 449-461$, 2016.

안규성, 황인철, 김혜경. 산삼배양근이 함유된 생약추출물의 비듬균 Malassezia furfur에 대한 항균 활성. 국제보건미용 학회지, 7: 51-57, 2013.

안지영, 김준호, 권세욱, 김대기, 이강수, 이영미. 오미자를 함유한 복합물의 항균, 발한억제 및 소취효과. 동의생리병리학 회지, 26: 53-58, 2012.

오지영, 이복순, 김영철. 페파민트 오일의 모발성장 촉진효과 및 항비듬균 활성. 대한미용학회지, 10: 261-269, 2014.

정경애, 박찬성. 마늘, 생강, 양파 즙의 항산화능과 항균작용. 한국식품저장유통학회지, 20: 134-139, 2013.

최종화, 옥승호. Staphylococcus epidermidis를 억제하는 Graviola 추출물의 항균활성. 한국산학기술학회논문지, 18 :

667-673, 2017.

하유미, 이보배, 배희정, 제경모, 김순래, 최재석, 최인순. 피부질환 원인균에 대한 자몽종자추출물과 법제유황수의 항균

효과. 한국생명과학회지, 19: 94-100, 2009.

한은주, 김중만. 생강가루 첨가량에 따른 양갱의 품질 특성. 동아시아식생활학회지, 20: 360-366, 2011.

황은경, 이준구, 하재정, 오동엽, 김병기. 생강과 인삼분말 첨가가 돈육포의 물리화학적 특성에 미치는 영향. 농업생명과학 연구, 49: 173-187, 2015.

황현정, 유정식, 이하연, 권동주, 한웅, 허성일, 김선영. 잦나무 정유의 소취효과 및 구강균에 대한 항균활성 평가. 한국자 원식물학회지, 27: 1-10, 2014. 


\section{中文摘要}

\section{姜不同部位提取物的抑菌和除臭作用}

李榮淑 ${ }^{1} ，$ 姜英珠 ${ }^{2} ，$ 柳敏貞 ${ }^{3 *}$

${ }^{1}$ Su Mi 美容院, 大邱, 韩国

${ }^{2}$ Gat-eunsaeng-gag, 大邱, 韩国

3南部大学香匠美容学科, 光州, 韩国

目的: 使用姜中不同部位的提取物, 旨在评估其对皮肤菌群的抗菌作用以及对氨的除臭作用，从而确定其作为抗 菌成分和功能性草药化妆品成分的潜力。方法: 使用纸盘法检查对皮肤菌群的抗菌作用, 并通过气体检测法检查 对氨气的除臭作用。结果: 对姜的不同部分 (叶, 茎和根) 的提取物进行抗菌作用结果显示, 浓度为 $5 \mathrm{mg} / \mathrm{mL}$ 时, 对金黄色葡萄球菌的抗菌作用分别为 $3 \mathrm{~mm}, 3 \mathrm{~mm}$ 和 $2 \mathrm{~mm}$ 透明区; 对表皮葡萄球菌的抗菌作用, 分别为 $8 \mathrm{~mm}, 5 \mathrm{~mm}$ 和 $4 \mathrm{~mm}$ 的透明区域; 对痤疮丙酸杆菌（一种引起痤疮的细菌）的抗菌作用, 分别有 $4 \mathrm{~mm}, 3$ $\mathrm{mm}$ 和 $1 \mathrm{~mm}$ 的透明区域。对椭圆假单胞菌的抗菌作用分别有 $6 \mathrm{~mm}, 5 \mathrm{~mm}$ 和 $4 \mathrm{~mm}$ 的透明区域。对于糠 $M$ 分 支杆菌的抗菌作用分别为, $4 \mathrm{~mm}, 3 \mathrm{~mm}$ 和 $2 \mathrm{~mm}$ 的透明区域。对于白色念珠菌的抗菌作用分别为, 有 $4 \mathrm{~mm}$ , $3 \mathrm{~mm}$ 和 $2 \mathrm{~mm}$ 的透明区域。最后, 在评估浓度为 $5 \mathrm{mg} / \mathrm{mL}$ 时, 对薄荷癣菌的抗菌作用, 发现叶, 茎和根提 取物分别具有 $6 \mathrm{~mm}, 4 \mathrm{~mm}$ 和 $3 \mathrm{~mm}$ 的透明区域。在评估姜皮提取物对氨的除臭效果显示, 在 120 分钟时, 叶，茎和根提取物的除臭效果分别为 $98 \% ， 95 \%$ 和 $91 \%$ 。结论: 在姜皮的三种提取物中，叶提取物对七种类型 的皮肤菌群具有最高的抗菌作用以及最高的除臭作用, 因此证实了其作为抗菌成分和功能性草药化妆品成分的 潜力。

关键词: 姜, 抗菌剂，除臭，氨，化妆品 
